\title{
A Transparent Polyimide Film as a Biological Cell Culture Sheet with Microstructures
}

\author{
Hirotaka Maenosono, Hirofumi Saito, Yasushiro Nishioka* \\ Department of Precision Machinery, College of Science and Technology, Nihon University, Chiba, Japan. \\ Email: ${ }^{*}$ nishioka@eme.cst.nihon-u.ac.jp
}

Received September $1^{\text {st }}, 2013$; revised December $14^{\text {th }}, 2013$; accepted December $28^{\text {th }}, 2013$

Copyright (C) 2014 Hirotaka Maenosono et al. This is an open access article distributed under the Creative Commons Attribution License, which permits unrestricted use, distribution, and reproduction in any medium, provided the original work is properly cited. In accordance of the Creative Commons Attribution License all Copyrights (C) 2014 are reserved for SCIRP and the owner of the intellectual property Hirotaka Maenosono et al. All Copyright (c) 2014 are guarded by law and by SCIRP as a guardian.

\begin{abstract}
The research on stem cell cultures has attracted much attention due to the recent development of regenerative medicine. Therefore, higher functionalities for devices used for culturing cells are strongly demanded. In this study, we fabricated cell culture sheets using transparent polyimide (PI), parylene (PA), and polyetheretherketone (PEEK) to make polymer materials that had microstructures. We then cultured stromal marrow cells (OP9) on them and investigated the cell alignment within the microstructures. Hot embossing was used to fabricate the microstructures with a width and depth of $5 \mu \mathrm{m}$ on the polymer substrates. Cultivation of the cells was confirmed on the transparent PI and PA sheets, however, it was not observed on the PEEK sheet. Slight alignment of the cells was also observed along with the microstructures.
\end{abstract}

\section{KEYWORDS}

Transparent Polymide; Parylene; Polyetheretherketone; OP9 Cell; Hot Embossing

\section{Introduction}

In recent years, the research on stem cell cultures has been actively performed in order to generate cell populations for the functional recovery of human body parts lost by illness or injury [1,2]. Polymer materials have attracted attention in this field because they have biocompatibility, good mechanical properties, and outstanding moldability. Moreover, polymers are flexible and cheap when compared to glass materials. Polymer materials are often used as cell culture sheets [3], and polymer substrates with fabricated microstructures have been reported to support the culture of biological cells [3,4]. Polymer materials in the form of elastomeric gels, porous bodies, films, and particles are suitable substrates for a biomatrix, and can be applied for the culture of complex living systems. In particular, the porous scaffold fabricated on the cells culture substrate promotes cell growth and survival and reproduces the three-dimensional environmental microcosm that is normally present in the living body [4-9].

*Corresponding author.
These reports show that the cell culture is greatly influenced by the fabricated structure. Moreover, the porous scaffold has to have a structure that is appropriate for the intended purpose; the scaffold system has to have a small surface so that the seeding density of cells is at maximum.

Culture systems in which osteoblasts were grown in a straight-line structure made of PI, whose width and depth were $5 \mu \mathrm{m}$ have been reported [10]. In this report, the substrate material used was PI alone and the fabricated structure was a linear shape. The culture of stromal marrow cells (OP9), interstitial cells generated from bone marrow, has been attracting research attention. This is because stromal marrow cells enhance growth factor production, and support multiplication and specialization of hematopoietic stem and precursor cells. Use of these cells has been applied through tissue engineering to generate blood and bone progenitors [4,11-17].

It is anticipated that fabricating fine structures and controlling the growth of different stem cells will allow the generation of sufficient cell populations for use in research or in the clinic setting. To this end, we thought 
to fabricate and evaluate a fine polymer-based structure in which cells can successfully align and proliferate. Polyimide (PI) has superior heat resistance, mechanical strength, and chemical stability. Therefore, PI is expected to withstand the high temperatures required for the sterilization process. PI-based microstructures have already been shown to be transferable by hot embossing and are therefore suitable for microelectromechanical systems (MEMS) fabrication processes [18-23]. However, conventional PI is not transparent and has an opaque tan color, which would make it difficult to observe any cells cultured on PI sheets. Therefore, we focused on transparent PI, which recently became commercially available [24].

In this study, we fabricated microstructures on cell culture sheets composed of transparent PI, PA, and PEEK, and cultured OP9 cells on them. Using the mold fabricated with micromachining process technology, a capillary vessel model was transferred to each polymer substrate, and cultivation evaluation of OP9 was performed. Comparisons were then made between transparent PI, PA, and PEEK. Hot embossing was also used to fabricate microtrenches with a width and depth of $5 \mu \mathrm{m}$ on the polymer substrates.

\section{Cell Culture Principle}

In tissue engineering, it is important to grow cultured cells in an environment that reproduces the environmental microcosm in the living body artificially. It is expected that if this natural environment is accurately reproduced, the cells will exhibit functions similar to those it has in the living body.

Proteins work to promote cell activity [25]. If a culture solution is in contact with an artificial material, the protein in the liquid is first adsorbed onto the material surface. Any cultured cells are then in contact with the protein layer which is adsorbed on the material surface. The cells will then be adsorbed to the material surface through the protein layer, allowing them to extend. Cells in suspension fall onto the protein layer by gravity [26]. The cell and protein layer form physicochemical interactions, such as electrostatic interactions and hydrophobic bonds, which facilitate biological interactions between the integrins on the cells and glycoproteins in the protein layer thus promoting cell adhesion. Integrins near the fixed point form interactions to the adhesive glycoprotein in the protein layer further increasing the cell adhesion area. It has been reported that material surface conditions affect the adsorption of proteins to material surfaces greatly $[27,28]$. When the material surface is hydrophobic, the amount of protein adsorption increases. When it is hydrophilic, the amount of protein adsorption decreases. In addition, when the material surfaces have electric charge, the amount of protein adsorption increases. Cells with a hydrophilic surface stick to a hydrophobic surface most. If there is an electric charge, more cells are adsorbed whereas fewer cells are adsorbed on a hydrophilic surface. So, the adsorption density of a protein can be controlled by modulating the functional group of the material's surface [29]. Therefore, it is possible to make a hydrophilic portion and a hydrophobic portion selectively, and to change the adhesion of cells selectively.

The fatty series, which are amino acid to constitute protein, nonpolar fellows, the aromatic series show hydrophobicity, and a polar chain, the electric charge chain shows hydrophilicity. In solution, a hydrophobic molecule avoids contact with a water molecule, and tries to gather mutually. Therefore, hydrophobic molecules are combined. In an electrostatic interaction, molecules with an electric charge act mutually. The amino acid that shows hydrophilicity acts with the inside of a molecule, or a water molecule, and generates gravitation and repulsion. Thereby, adsorption of the protein is controlled [30, 31].

The process of cell culture uses aseptic techniques, for preparation of cells, selection of the culture medium with the cells, and culture of the cells. Asceptic techniques are also used when cell passages are performed. It is necessary to sterilize any experimental devices especially in animal and human experiments, to prevent contamination by microbes. Next, adjustment of the culture medium and the reagents is performed. A culture medium is selected according to the type of cell being cultured and is supplemented with an optimal dose of antibiotics. If cultured cells are adherent, they are detached from the cell surface by using the enzyme, trypsin. Seeding of the detached cells is performed by pipetting the cell suspension in fresh culture medium. Cells will reattach to the material surface and grow if the culture medium is adjusted appropriately. Also during cultivation, the $\mathrm{pH}$ of the culture medium inclines towards a basic $\mathrm{pH}$ under the atmosphere, therefore it is necessary to adjust the $\mathrm{pH}$ of the culture medium. Animal cells have a $\mathrm{pH}$ range between 6.6 and 7.8, and though they can survive in a comparatively wide $\mathrm{pH}$ range, the optimal range is usually 7.2 7.4. Therefore, it is necessary to put the cells cultured in medium in a $\mathrm{CO}_{2}$ incubator and to adjust the $\mathrm{pH}$ where it is not taken out other than for observation.

\section{Experimental Conditions}

We focused on the highly efficient polymer that has functionality, biocompatibility, appropriate mechanical properties, and high thermal resistance as a substrate material for cell culture sheets. In particular, we focused on transparent PI, PA, and PEEK polymers, which are currently used in the manufacture of medical devices. Four different fine micron-sized structures were fabricated on the cell culture sheets and compared. The sili- 
con (Si) mold was fabricated by photolithography and ICP dry etching which are MEMS manufacturing processes, while the hot embossing method was used to transfer the fine structure to the substrate material.

The plans for the cell culture sheet are shown in Figure 1 , and the design enlargement of the fine structure is depicted in Figure 2. In the design of the cell culture sheet, the substrate size was the square of $4 \mathrm{~cm}^{2}$, and the line width and depth were $5 \mu \mathrm{m}$. The fine structure had a hexagonal structure with a different angle. The hexagon structure number was increased for every one line, and 25 lines of it were fabricated. Thus, the fabricated triangle structure had a gross structure. The angle of each triangle structure is $15^{\circ}, 30^{\circ}, 45^{\circ}$, and $60^{\circ}$. A length of one side is $100 \mu \mathrm{m}$ with a $60^{\circ}$ structure. The thickness of the cell culture sheets was $200 \mu \mathrm{m}$ of transparent PI and PA; PEEK was $250 \mu \mathrm{m}$. OP9 cells were cultured on the structures in Alpha-MEM containing 20\% fetal bovine serum. Alpha-MEM is a culture medium for cell cultures requiring L-alanyl and L-glutamine. It is used for stromal marrow cells cultivation and mesenchymal stem cell cultivation. Since fetal bovine serum contains a protein that promotes cell adsorption, it is suitable for cell culture. The conditions of the $\mathrm{CO}_{2}$ incubator were kept at $37^{\circ} \mathrm{C}$, and $5 \%$ of $\mathrm{CO}_{2}$ concentrations similar to in vivo mammalian conditions.

\section{Experiment Method}

\subsection{Cell Culture Sheet Production Process}

The manufacturing process that was used to generate the fine structure Si mold is shown in Figure 3. Spin coating of the photoresist (s-1830) was performed on the Si substrate, and prebake was performed for 20 minutes at $90{ }^{\circ} \mathrm{C}$. Next, exposure was performed using the photomask

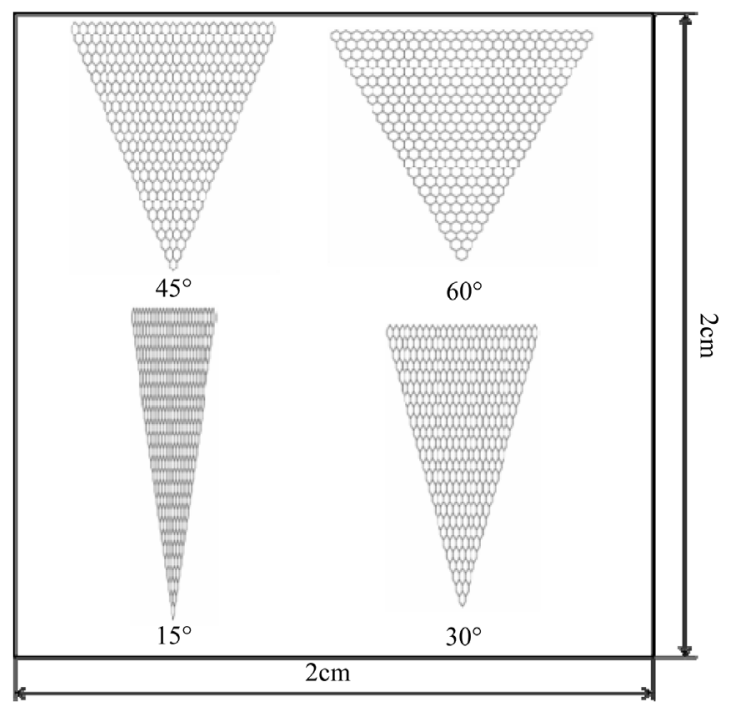

Figure 1. Design of microstructures on substrate.

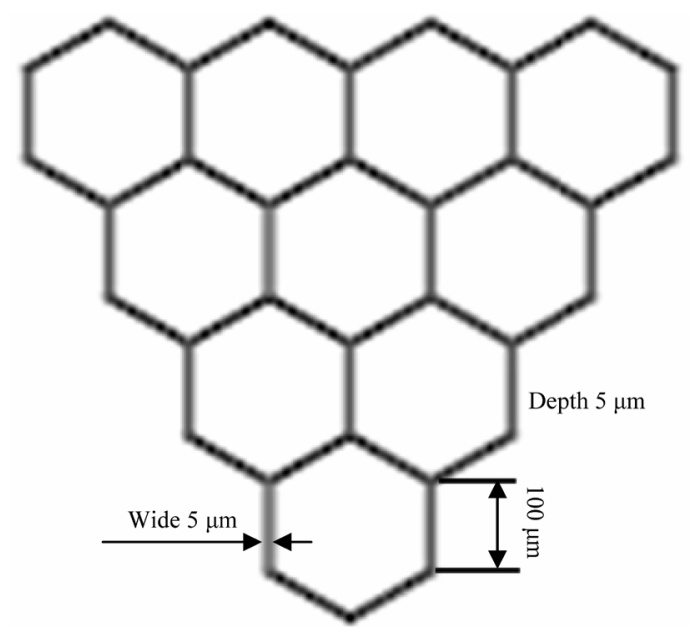

Figure 2. Enlarged view.

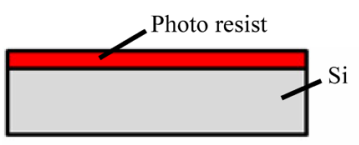

(a) Spin coating

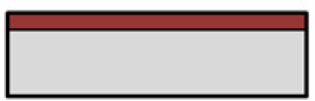

(b) Prebaking

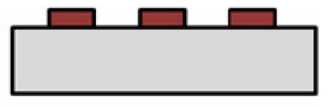

(d) After development and posts bake

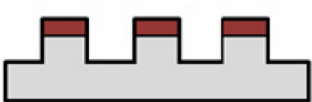

(e) ICP dry etching of $\mathrm{Si}$

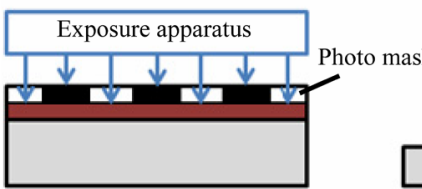

(c) Exposure

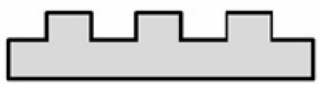

(f) Completion after
resist removal
Figure 3. Si mold manufacturing process for cell culture sheets.

with the fine patterns, and these patterns were transferred using a developing solution (MF-319). Then, posts bake was performed for 30 minutes at $120^{\circ} \mathrm{C}$, and $\mathrm{Si}$ was etched by ICP dry etching. The photoresist was removed with acetone, to complete the mold.

The hot embossing fabrication methods are depicted in Figure 4. The substrate polymer materials and the $\mathrm{Si}$ mold were heated beyond the glass transition temperature. The mold was then pressed onto the substrate, and was released after cooling. The hot embossing time was $180 \mathrm{~s}$, and a molding pressure of $400 \mathrm{~Pa}$ was applied to an area of $4 \mathrm{~cm}^{2}$. The molding temperatures were $300^{\circ} \mathrm{C}$ for transparent PI, $260^{\circ} \mathrm{C}$ for $\mathrm{PA}$, and $180^{\circ} \mathrm{C}$ for PEEK, respectively.

The cell culture sheets fabricated are shown in Figure 5.

\subsection{Cell Culture Process}

The outline of the cell culture process is described in 


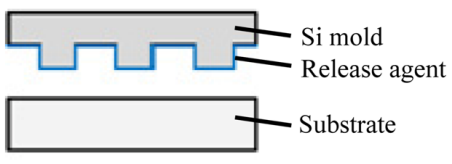

(a) Si mold and substrate were heated

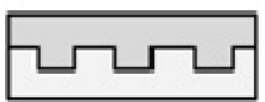

(b) Pressing

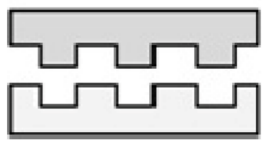

(c) Mold release

Figure 4. Fabrication process for cell culture sheets.

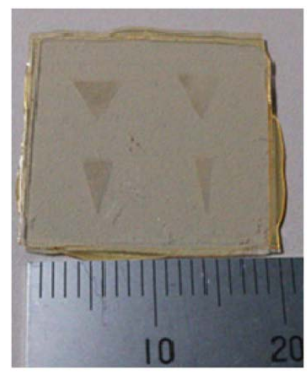

(a) Transparent PI

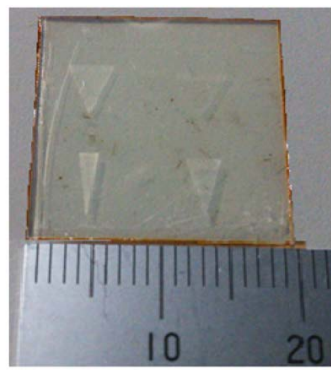

(b) PA

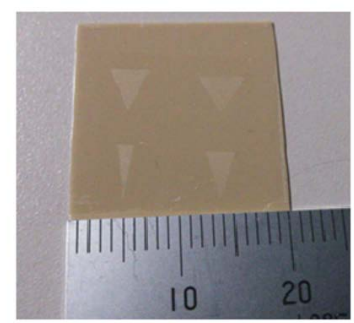

(c) PEEK

Figure 5. Fabricated cell culture sheets for each material.

Figure 6. The polymer sheets underwent dry heat sterilization for 60 minutes at $120^{\circ} \mathrm{C}$. When putting in the polymer sheets in dry heat sterilization, they were packed in aluminum foil. Since OP9 cells adhered to the cultivation vessel, it was necessary to exfoliate it from vessel. Therefore, the culture medium was aspirated. OP9 cells were washed in phosphate-buffered saline twice to remove serum ingredients. To phosphate-buffered saline, in order to prevent contamination, the antibiotic (penicillin-streptomycin) was mixed. After washing, phosphatebuffered saline was aspirated. In addition, the cells were re-adhered on the substrate through the protein layer. The protein which adhered to the vessel promoted the adhesion of the cells. Thereafter, attachment-enhancing proteins were digested by trypsin. Since trypsin damages cells, processing time was minimized, and only a small quantity was used. During trypsinization, the cells were

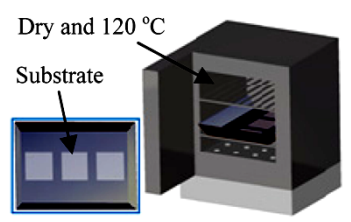

(a) Sterilization treatment

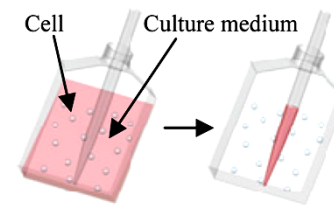

(b) A culture medium is aspirated

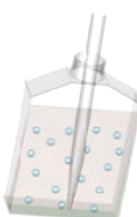

(c) Wash

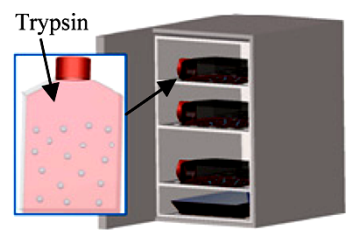

(d) Exfoliation

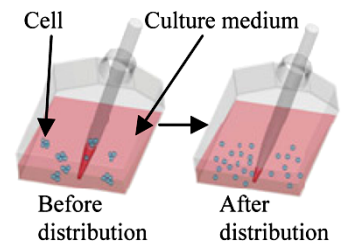

(e) Distribution of cells

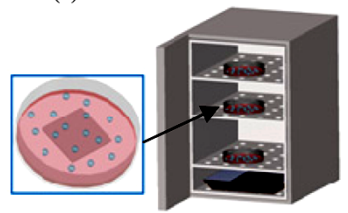

(f) Placed in the $\mathrm{CO}_{2}$ incubator
Figure 6. Cell culture process.

placed in a $\mathrm{CO}_{2}$ incubator to maintain the $\mathrm{pH}$. Cells were then pipetted up and down to make an evenly distributed cell suspension. Pipetting was only performed about 3 10 times so as not to damage the cells. The sterilized cell culture sheets were placed onto a nutrient medium. The OP9 cells were then seeded on the sheets, placed in the $\mathrm{CO}_{2}$ incubator, and cultured for $24 \mathrm{~h}$.

\section{Results and Discussion}

The distribution of OP9 cells on each substrate material is shown in Figure 7. The defect, which occurs in the portion that the channel intersects as the arrow shows, is a defect of the substrate, which occurred when removing the mold from the substrate. The cells on the sheets were evaluated optically. No special surface treatment was applied, and the surfaces of these polymer sheets were used as received from the manufacturer. OP9 cells were successfully cultured on the transparent PI sheet and PA sheet, but not on the PEEK sheet. Because the PI and PA sheets were transparent, the cultured cells were easily observed using an optical microscope. Figure 8 shows the contact angles between these polymer films and DI water. The surfaces of the transparent PI and PA were sufficiently hydrophobic to culture OP9 cells, whereas the PEEK sheet was not.

Comparison examination of the culture results of transparent PI and PA were performed. The culture results of OP9 cells on transparent PI and PA substrate are shown in Figure 9.

As shown in Figure 9, the cultured cells were able to align to the fine structure. Comparing the transparent PI and PA, the transparent PI showed growth of more cells 


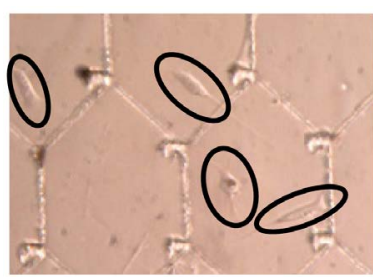

(a) Transparent PI

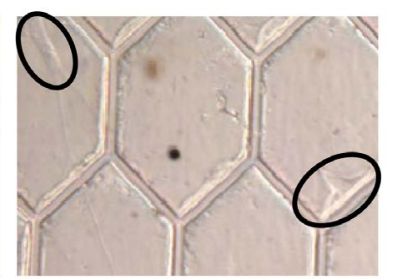

(b) PA

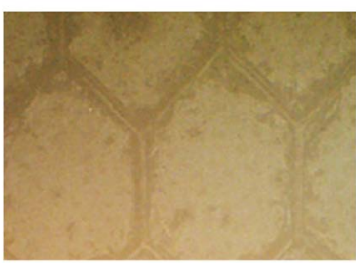

(c) PEEK

Figure 7. Culture result for each material.

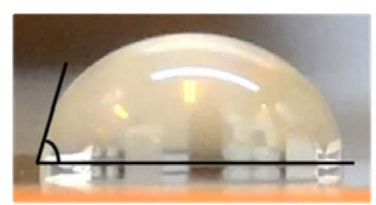

(a) Transparent $\operatorname{PI}\left(\sim 75^{\circ}\right)$

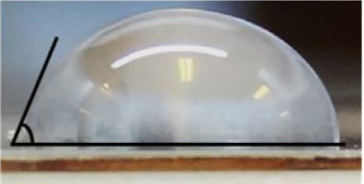

(b) $\mathrm{PA}\left(\sim 65^{\circ}\right)$

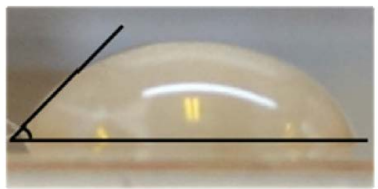

(c) $\operatorname{PEEK}\left(\sim 45^{\circ}\right)$

Figure 8. Contact angle between DI water and substrates.

than PA did. Cell adhesion on the inside channels of the fine structure was not observed. If a microstructural area was large, the number of cells that adhered within an area seemed to increase.

Transparent PI was most suitable for cell cultivation once each polymer material was evaluated. Cells were also successfully cultured on PA but not on PEEK. For this reason, the relationship between protein adsorption and cell adhesion should be considered. The surface conditions of the polymer materials used in this study, suggest that transparent PI is near hydrophobicity and PEEK is near hydrophilicity. One possible solution for this is to increase the charge or hydrophobicity of the substrates surface by using a plasma treatment. This would increase protein adsorption and promote cell adhesion.

Cell alignment with the fabricated fine structure was observed slightly. This brings to light an issue with the culturing method. When putting cells into a cultivation vessel, seeding of cells are performed as a whole, but since cells fall by gravity, there is a stochastic change to how they adhere. It may be that because the culture surface is a larger vessel as compared to the substrate, cell adhesion to the substrate decreases stochastically, and

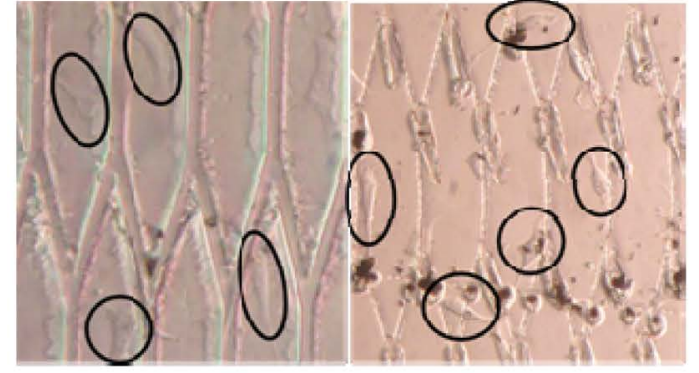

$15^{\circ}$ (left) PA (right) Transparent PI
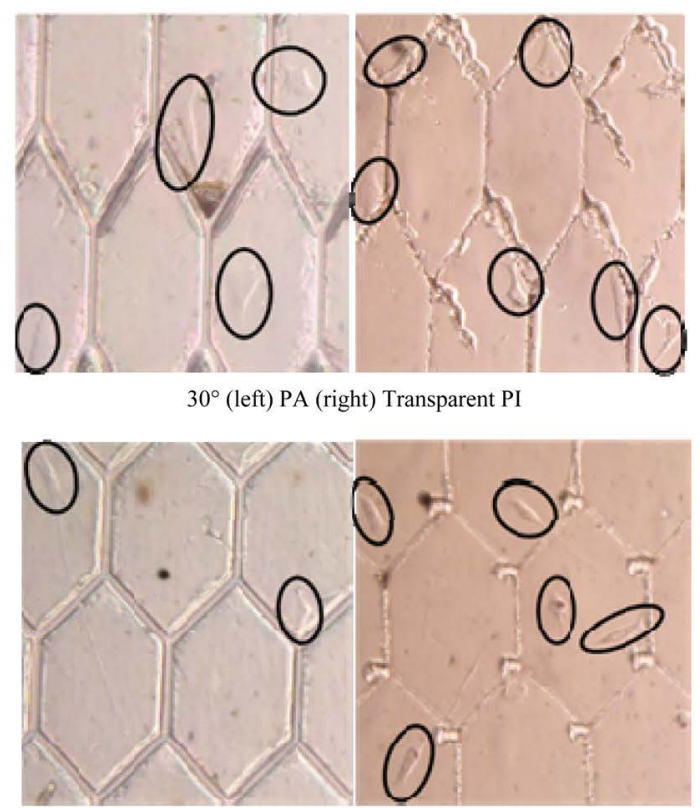

$45^{\circ}$ (left) PA (right) Transparent PI

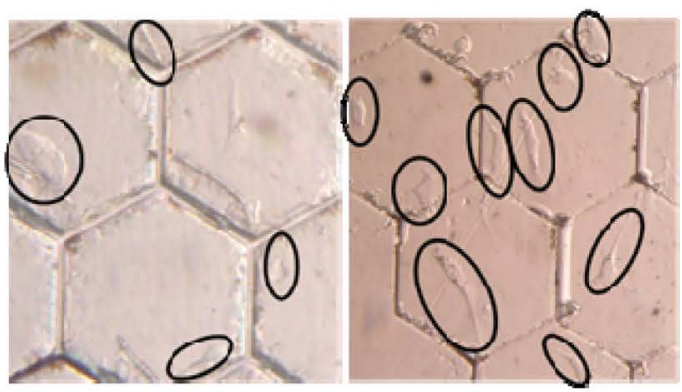

$60^{\circ}$ (left) PA (right) Transparent PI

Figure 9. Culture result comparison for each material.

obstructs adhesion to the structures alignment. Moreover, it could also be that because the area of the fabricated hexagon structure is large and cell adhesions to the structures decreases stochastically. As a solution, a fine structure should be reexamined, with a hydrophilic portion and a hydrophobic portion selectively arranged on the structure, and it is possible to control adhesion of cells near the structure. In addition, the number of cells in a container was about 80,000 per $200 \mu \mathrm{l}$, and it is possible that number of cells was insufficient. Shortage of sterilization processing should also be considered. It is neces- 
sary to improve the sterilization and to perform more thorough sterilization processing. Moreover, the $24 \mathrm{~h}$ culture time used in this study may have been too short, and this should be taken into consideration when interpreting the results.

\section{Conclusion}

We evaluated a transparent PI film as a cell culture sheet in comparison with PA and PEEK films that had been previously used in cell culture sheets. We fabricated microtrenches with a width and depth of $5 \mu \mathrm{m}$ on these polymer films by hot embossing, and then cultivated OP9 stromal marrow cells on the sheets. The culture results of each substrate material were compared and culture in cells was able to be observed by the transparent PI and PA substrate, but was not observed in a PEEK substrate. Transparent PI had the most optimal structure for cell culture. Interestingly, the cells adhered in slight alignment to the fabricated fine structure. Since the cell adhesion to the fine structure was observed, it may be possible to cultivate in accordance with structure by improving experimental conditions. The cells grown on the transparent PI were easily observed using an optical microscope.

\section{Acknowledgements}

This research was performed in the Micro Functional Device Research Center of CST, Nihon University.

\section{REFERENCES}

[1] A. H. Reddi, "Morphogenesis and Tissue Engineering of Bone and Cartilage: Inductive Signals, Stem Cells, and Biomimetic Biomaterials," Tissue Engineering, Vol. 6, No. 4, 2000, pp. 351-359.

http://dx.doi.org/10.1089/107632700418074

[2] G. Keller, "Embryonic Stem Cell Differentiation: Emergence of a New Era in Biology and Medicine," Genes \& Development, Vol. 19, No. 10, 2005, pp. 1129-1155. doi: 10. 1101/gad.1303605

[3] T. L. Charest, M. T. Eliason, A. J. Garcia and W. P. King, "Combined Microscale Mechanical Topography and Chemical Patterns on Polymer Cell Culture Substrates,” Biomaterials, Vol. 27, No. 11, 2006, pp. 2487-2494. doi: 10. 1016/j.biomaterials.2005.11.022

[4] S. Taqvi and K. Roy, "Influence of Scaffold Physical Properties and Stromal Cell Coculture on Hematopoietic Differentiation of Mouse Embryonic Stem Cells," Biomaterials, Vol. 27, No. 36, 2006, pp. 6024-6031. http://dx.doi.org/10.1016/j.biomaterials.2006.05.052

[5] N. S. Hwang, S. Varghese and J. Elisseeff, "Controlled Differentiation of Stem Cells," Advanced Drug Delivery Reviews, Vol. 60, No. 2, 2008, pp. 119-214. doi: 10. 1016/j.addr.2007.08.036

[6] A. Khademhosseini, R. Langer, J. Borenstein and J. P.
Vacanti, "Microscale Technologies for Tissue Engineering and Biology," Proceedings of the National Academy of Sciences, Vol. 103, No. 8, 2006, pp. 2480-2487. doi: 10. 1073/pnas.0507681102

[7] S. Levenberg, N. F. Huang, E. Lavik, A. B. Rogers, J. Itskoviz-Eldor and R. Langer, "Differentiation of Human Embryonic Stem Cells on Three-Dimensional Polymer Scaffolds," Proceedings of the National Academy of Sciences, Vol. 100, No. 22, 2003, pp. 12741-12746. doi: 10. 1073/pnas. 1735463100

[8] S. Battista, D. Guarnieri, C. Borselli, S. Zeppetelli, A. Borzacchiello, L. Mayol, D. Gerbasio, D. R. Keene, L. Ambrosio and P. A. Netti, "The Effect of Matrix Composition of 3D Constructs on Embryonic Stem Cell Differentiation,” Biomaterials, Vol. 26, No. 31, 2005, pp. 6194-6207.

[9] S. Yang, K. Leong, Z. Du and C. Chua, "The Design of Scaffolds for Use in Tissue Engineering Part I. Traditional Factors," Tissue Engineering, Vol. 7, No. 6, 2001, pp. 679-689. http://dx.doi.org/10.1089/107632701753337645

[10] J. L. Charest, L. E. Bryant, A. J. Garcia and W. P. King, "Hot Embossing for Micropatterned Cell Substrates," Biomaterials, Vol. 25, No. 19, 2004, pp. 4767-4775. http://dx.doi.org/10.1016/j.biomaterials.2003.12.011

[11] A. Noghero, F. Bussolino and A. Gualandris, "Role of the Microenvironment in The Specification of Endothelial Progenitors Derived from Embryonic Stem Cells,” Microvascular Research, Vol. 79, No. 3, 2010, pp. 178-183. http://dx.doi.org/10.1016/j.mvr.2009.12.008

[12] A. I. Caplan, "Mesenchymal Stem Cells," Journal of Orthopaedic Research, Vol. 9, No. 5, 1991, pp. 641-650. http://dx.doi.org/10.1002/jor.1100090504

[13] D. J. Prockop, "Marrow Stromal Cells as Stem Cells for Nonhematopoietic Tissues,” Science, Vol. 276, No. 71, 1997, pp. 71-74. http://dx.doi.org/10.1126/science.276.5309.71

[14] M. A. Vodyanik, J. A. Bork, J. A. Thomson and I. I. Slukvin, "Human Embryonic Stem Cell-Derived CD34 ${ }^{+}$ Cells: Efficient Production in the Coculture with OP9 Stromal Cells and Analysis of Lymphohematopoietic Potential,” Blood, Vol. 105, No. 2, 2005, pp. 617-626. http://dx.doi.org/10.1182/blood-2004-04-1649

[15] P. Trivedi and P. Hematti, "Simultaneous Generation of $\mathrm{CD}^{+} 4^{+}$Primitive Hematopoietic Cells and $\mathrm{CD}^{+} 3^{+} \mathrm{Me}-$ senchymal Stem Cells from Human Embryonic Stem Cells Cocultured with Murine OP9 Stromal Cells,” Experimental Hematology, Vol. 35, No. 1, 2007, pp. 146-154. http://dx.doi.org/10.1016/j.exphem.2006.09.003

[16] S. T. Fraser, J. Yamashita, L. M. Jakt, M. Okada, M. Ogawa, S. Nishikawa and S. Nishikawa, "In Vitro Differentiation of Mouse Embryonic Stem Cells: Hematopoietic and Vascular Cell Types,” Methods in Enzymology, Vol. 365, 2003, pp. 60-72. http://dx.doi.org/10.1016/S0076-6879(03)65004-4

[17] K. Kitajima, M. Tanaka, J. Zheng, E. Sakai-Ogawa and T. Nakano, "In Vitro Differentiation of Mouse Embryonic Stem Cells to Hematopoietic Cells on an OP9 Stromal Cell Monolayer," Methods in Enzymology, Vol. 365, 2003, pp. 73-83.

http://dx.doi.org/10.1016/S0076-6879(03)65005-6 
[18] H. Komatsuzaki, K. Suzuki, Y. Liu, T. Kosugi, R. Ikoma, S.-W. Youn, M. Takahashi, R. Maeda and Y. Nishioka, "Flexible Polymide Micropump Fabricated Using Hot Embossing," Japanese Journal of Applied Physics, Vol. 50, 2011, Article ID: 06GM09. http://dx.doi.org/10.1143/JJAP.50.06GM09

[19] R. Ikoma, H. Komatsuzaki, K. Suzuki, T. Komori, K. Kuroda, H. Saitou, S.-W Youn, H. Hiroshima, M. Takahashi, R. Maeda and Y. Nishioka, "Transfer of Relatively Large Microstructures on Polyimide Films using Thermal Nanoimprinting," Journal of Photopolymer Science and Technology, Vol. 25, No. 2, 2012, pp. 255-260. http://dx.doi.org/10.2494/photopolymer.25.255

[20] R. Ikoma, H. Komatsuzaki, T. Komori, K. Kuroda, H. Saito and Y. Nishioka, "Valveless Micropumps with Dual Polyimide Diaphragms," Applied Mechanics and Materials, Vol. 300-301, 2013, pp. 1364-1367. http://dx.doi.org/10.4028/www.scientific.net/AMM.300-3 $\underline{01.1364}$

[21] H. Saito, H. Komatsuzaki, R. Ikoma, T. Komori, K. Kuroda, Y. Kimura, Y. Fukushi, H. Maenosono, S. Koide, M. Satano and Y. Nishioka, "Electroosmotic Flow Pump on Transparent Polyimide Substrate Fabricated Using Hot Embossing," Applied Mechanics and Materials, Vol. 300301, 2013, pp. 1360-1363.

http://dx.doi.org/10.4028/www.scientific.net/AMM.300-3 $\underline{01.1356}$

[22] T. Komori, T. Kosugi, K. Kuroda, H. Saito, Y. Kimura, Y. Fukushi, H. Maenosono, S. Koide, M. Satano, R. Ikoma and Y. Nishioka, “Transfer Printing of Au Micropatterns on Polyimide Films, Journal of Photopolymer Science and Technology, Vol. 26, No. 3, 2013, pp. 309-312. http://dx.doi.org/10.2494/photopolymer.26.309

[23] Y. Fukushi, S. Koide, R. Koma, W. Akatsuka, S. Tsujimura and Y. Nishioka, "Fabrication and Characterization of Glucose Fuel Cells with Microchannels Fabricated on Flexible Polyimide Film,” Journal of Photopolymer Science and Technology, Vol. 26, 2013, pp. 303-308. http://dx.doi.org/10.2494/photopolymer.26.303

[24] Product Name: Neopulim L. Mitsubishi Gas Chemical Company, INC., Tokyo, Japan, 2013. http://www.mgc.co.jp/eng/index.html

[25] I. M. Herman, N. J. Crisona and T. D. Pollard, "Relation between Cell Activity and the Distribution of Cytoplasmic Actin and Myosin,” The Journal of Cell Biology, Vol. 90, No. 1, 1981, pp. 84-91. http://dx.doi.org/10.1083/jcb.90.1.84

[26] L. B. Buravkova, Y. A. Romanov, N. A. Konstantinova, S. V. Buravkov, Y. G. Gershovich and I. A. Grivennikov, "Cultured Stem Cells Are Sensitive to Gravity Changes,” Acta Astronautica, Vol. 63, No. 5-6, 2008, pp. 603-608.

[27] W. M. Saltzman, “Cell Interactions with Polymers,” In: R. P. Lanza, R. Langer and J. Vacanti, Eds., Principles of Tissue Engineering, Elsevier, Amsterdam, 1996, pp. 221235.

[28] C. S. Izzard and L. R. Lochner, "Cell-to-Substrate Contacts in Living Fibroblasts: An Interference Reflexion Study with an Evaluation of the Technique,” Cell Science, Vol. 21, No. 1, 1976, pp. 129-159.

[29] P. Roach, D. Farrar and C. C. Perry, "Surface Tailoring for Controlled Protein Adsorption: Effect of Topography at the Nanometer Scale and Chemistry," Journal of the American Chemical Society, Vol. 128, No. 12, 2006, pp. 3939-3945.

[30] T. E. Creighton, "Proteins: Structures and Molecular properties-2ndedition,” W. H. Freeman \& Company, New York, 1993.

[31] C. R. Cantor and P. R. Schimmel, "Biophysical Chemistry Part I: The Conformation of Biological Macromolecules,” W. H. Freeman \& Company, New York, 1980. 